\title{
The teaching of Kiswahili in Kenyan Universities with emphasis on historiography
}

\section{Nathan Oyori Ogechi}

\section{Q OpenEdition}

1 Journals

\section{Electronic version}

URL: https://journals.openedition.org/eastafrica/601

DOI: 10.4000/eastafrica.601

ISSN: 2790-1076

\section{Publisher}

IFRA - Institut Français de Recherche en Afrique

\section{Printed version}

Date of publication: 1 September 2008

Number of pages: 151-165

ISSN: 2071-7245

\section{Electronic reference}

Nathan Oyori Ogechi, "The teaching of Kiswahili in Kenyan Universities with emphasis on

historiography", Les Cahiers d'Afrique de l'Est / The East African Review [Online], 40 | 2008, Online since 07 May 2019, connection on 09 December 2021. URL: http://journals.openedition.org/eastafrica/601 ; DOl: https://doi.org/10.4000/eastafrica.601

This text was automatically generated on 9 December 2021.

Les Cahiers d'Afrique de l'Est / The East African Review 


\title{
The teaching of Kiswahili in Kenyan Universities with emphasis on historiography
}

\author{
Nathan Oyori Ogechi
}

\section{Introduction}

1 It is almost two score years today since the inception of the first university in Kenya. In addition, it is at present official that Kiswahili is not only a national language but also a co-official language in the country (Myers-Scotton 1993, Ogechi 2002, 2003). Furthermore, the language is one of the working languages of the East African Community and the African Union. For a long time, the language has been taught in many universities and institutions across the globe. Notable universities where Kiswahili is taught in Europe include Berlin, Leipzig, Hamburg, Paris, etc.

Whereas the approach of teaching Kiswahili and other African languages in those universities has been studied and documented (e.g. Hurskainen 2001), to my knowledge, no inquiries have focused on the teaching of Kiswahili in Kenyan universities. Thus many questions remain unanswered, namely, how was Kiswahili as a discipline at the university established? Who are taught Kiswahili? What is the main focus in the teaching of Kiswahili in Kenyan universities? Does the content satisfy the clientele and job market? What are some of the latest developments in teaching and research into Kiswahili?

3 The present paper attempts to answer the foregoing questions through a historiographic approach. It is divided into five sections. In section 2, I sketch the framework upon which the analysis is premised. The framework itself is a brief survey of the rise of universities and university education in Kenya. Section 3 discusses how the discipline of Kiswahili teaching and research was established and who were the teachers and researchers. In section 4, I unmask what is presently taught in selected universities, and the challenges the scholars face. I summarize and conclude in 5. 


\section{University education in Kenya}

The advent of universities in Kenya cannot be divorced from European imperialism and its aftermath. As Ogot (2005: 565), has observed:

The first modern universities come into existence at a time when Europe was in state of intellectual, political and religious turmoil, partly as a result of the struggle between the "two powers", the state and the church, and partly because they come into being in the social and cultural situation of the gradual emergence and development of the medieval urban civilization as its component.

What we have in Kenya are modern universities. In total there exist 26 universities, seven of which are so-called public universities with state sponsorship and several privately owned universities largely sponsored by different religions prominently Christian and Islamic. Eleven private universities have been granted government charter to offer degree programmes while the rest have letters of interim authority to operate. In addition, private international universities largely American, European and Australian also do have their satellite campuses in Kenya. To fully appreciate university education in Kenya, there is need to unravel the historical rise and development of universities in Kenya.

In 1947, the colonial government in Kenya conceived of a plan to start a Technical and Commercial Institute in Nairobi. This seed grew into an East African idea by 1949. Thus in 1951, a Royal Charter, "Royal Technical College of East Africa" was given. With grants coming from the Colonial Development and Welfare Funds, the Governor, Sir Phillip Mitchel laid the foundation stone for the Royal Technical College of East Africa in April 1952.

7 Meanwhile, the Asian Community through the Gandhi Memorial Academy Society in Kenya wanted to start a college of arts, science and commerce in memory of Mahtma Gandhi. Realizing what the government was doing, the Gandhi Memorial Academy Society joined hands with the East African governments in the Royal Technical College of East Africa in April 1954. In return, the society was given representation on the governing council of the college. Gauging from what the two players conceived before the college was began, one can safely argue that the initial focus of the college was technical courses (East African government's idea) and arts, science and commerce (Asian community's idea). The college admitted its first students in April 1956.

By 1958, a need was felt to expand the college into a second InterTerritorial University College of East Africa. On $25^{\text {th }}$ June 1961, the East African governments passed an Act of the East African High Commission that transformed the Royal Technical College into a second University College of East Africa. It was named the "Royal College Nairobi". This was renamed as the "University College of Nairobi" on $20^{\text {th }}$ May, 1964. In the subsequent years, several faculties and colleges were established.

In 1963, the University of East Africa was inaugurated and was the centre university education for Kenya, Uganda and Tanzania. The University of East Africa was dissolved on $1^{\text {st }}$ July 1970 and the three countries established their own national universities. By an Act of Parliament, the University of Nairobi was inaugurated by the then Chancellor, the late President Mzee Jomo Kenyatta on $10^{\text {th }}$ December 1970.

The University of Nairobi remained the only university in Kenya until 1984. Through the Moi University Act 1984, Moi University was established as the second public 
university in Kenya. Since then other public universities have been established, namely, Kenyatta University, Egerton University, Jomo Kenyatta University of Agriculture and Technology, Maseno University and Masinde Muliro University of Science and Technology, Kakamega. Besides the public universities, there exist several private universities such as University of Eastern Africa, Baraton (UEAB), Catholic University of Eastern Africa (CUEA), Daystar, United States International University (USIU), and Kenya Methodist University (KEMU) among others.

11 As indicated earlier, the focus of teaching at the University of Nairobi was not only technical education but also arts, science and commerce. The Mackay Report (ROK 1981) that led to the establishment of Moi University, recommended that the second university be a university of science and technology. Other universities such as Masinde Muliro of Science and Technology and Jomo Kenyatta University of Agriculture and Technology were established with natural science and technology in mind. However, they eventually embraced arts-based courses. At the moment, most public universities, including the two just mentioned have arts courses including Kiswahili.

\section{Advent of research and teaching of kiswahili}

12 As already indicated in the foregoing section, university education is not older than the number of years that Kenya has been independent. Thus whereas the first professor of African languages including research and teaching of Kiswahili in Europe was appointed in the second half of the $19^{\text {th }}$ Century (e.g. University of Berlin), research into and the teaching of Kiswahili in Kenyan Universities did not occur until after independence (1963). Even then the teaching of Kiswahili did not commence immediately after attaining independence. To understand how the discipline was established, one must appreciate the official language policy concerning Kiswahili since independence.

13 It is notable that during the struggle for independence Kiswahili had proved to be a useful language of inter-ethnic communications. Hence when Kenya won her independence, the late President Kenyatta addressed parliament in Kiswahili and declared that soon Kenya will transact all her business in Kiswahili regardless of what people say (Amidu 1995). In 1964, the government appointed a commission of inquiry into education chaired by Prof. Ominde (popularly known as the Ominde Commission, ROK 1964) to study what a young nation needed to realize fruitful results in human resource development. Concerning Kiswahili, the commission recommended that there was need to teach it but there will be no exam at the end of the primary cycle (Ogechi 2004). In high school, the teaching and examination of Kiswahili was left to individual schools to decide whether or not teach it. This policy was reversed through the Gachathi Commission (ROK 1976) that recommended that Kiswahili be taught and examined in CPE. However this was not implemented until 1985 following the Mackay Commission (ROK 1981) recommendation that made Kiswahili a compulsorily taught and examinable subject up to Grade Twelve.

14 Meanwhile in 1969, the late President Kenyatta had made a proposal to have Kiswahili used in parliament-a move that was followed by a constitutional amendment that made Kiswahili a language of parliamentary debate in 1974 (Amidu 1995: 62). It was during President Moi's tenure (1978-2002) that the use of Kiswahili in parliament was 
enhanced when he nominated some MPs who were only able to communicate in Kiswahili but spoke no English (e.g. Hon. Mulu Mutisya, Hon. Kariuki Chotara, Hon. Ezekiel Barng'etuny ${ }^{1}$ ).

15 In spite of the favourable move by pesidents Kenyatta and Moi regarding Kiswahili, influential elite (especially in the Kenyatta government ${ }^{2}$ ) were sharply opposed to the use of Kiswahili. Nevertheless, change like death was inevitable and Kiswahili now has a special place in the Kenyan society both in public and in universities.

\section{Research and teaching of kiswahili in Kenyan universities}

This sub-section explores the teaching of Kiswahili in a few Kenyan universities. In total, I examine research and teaching in four universities, two public (University of Nairobi and Moi University) and two private universities (University of East African, Baraton and Catholic University of East Africa).

\subsection{University of Nairobi}

17 Kiswahili is taught as Kiswahili studies at the University of Nairobi in the Department of Linguistics and African Languages that was established in 1970. For a long time, the focus of research and teaching has been linguistics and literature. The department has foci in Swahili Studies, Linguistics and African Languages, Linguistics and English, Arabic Studies and German Studies. Students in Swahili Studies take courses in linguistics and literature. However, only literature was, for a long time, taught in Kiswahili while linguistics was taught in English. As King'ei (2002: 224) observed, research and teaching in Kiswahili focuses on language, linguistics and literature. At its infancy, some of the senior faculty in the department were both local (Kenyans) and foreign (Europeans and Africans). The Kenyans included Prof. Abdulaziz, Prof. Mutahi and Prof. Omondi while foreigners included Myers-Scotton, Bernd Heine, Rainer Vossen (Europeans) and Francis Katamba (Uganda).

Perhaps due to the background of the lecturers in the department, Kiswahili was taught in English. For instance, Dr. Katamba taught phonetics and phonology in English, as did the European lecturers. Prof. Mutahi taught a course on the history and development of Kiswahili in Kiswahili in the 1977/1978 academic year for the first time (p.c Mr. Alan Opija-a student then). Otherwise, previously all linguistics courses were taught in English. Concerning postgraduate studies, King'ei (2002:224) reports that although MA theses on Kiswahili are written in Kiswahili, all PhD theses are written in English to date. It is worth noting that the first MA thesis was written in Kiswahili in 1988 (Mr. Davies Mukuriah).

The teaching of Kiswahili at the University of Nairobi has undergone some transformation. To begin with, there existed a department of Kiswahili at Kikuyu Campus (it largely trains teachers) and there were plans to start a department of Kiswahili at the Main Campus in 2006 (p.c. Dr. Mwenda Mbatia, Dr. John Habwe and Dr. Kyalo Wamitila). However, this became a cropper and the department of Kiswahili at Kikuyu was merged with the Department of Linguistics and African Languages at the Nairobi City Main Campus. In spite of this, all undergraduate and postgraduate courses 
in Swahili studies are taught in Kiswahili-thanks to the presence of Swahili-speaking Kenyan lecturers. However, PhD theses still continue to be written in English.

\subsection{Moi University}

This is one of the two public universities out of the seven with a department of Kiswahili. It was started as the second university in Kenya with a special focus on Science and Technology. However, to give the graduates a human and social science face, it was recommended that a School of Social, Cultural and Development Studies be established with Kiswahili as one of the disciplines. Kiswahili was to be one of the compulsory courses to be taught to all students regardless of their areas of specialization. This was recommended on the commission's recognition that graduates from higher institutions of learning were unable to transfer their knowledge to the masses that use Kiswahili and not English in their day to day communication.

The department of Kiswahili was started in 1987 when arts courses were introduced at Moi University. Though the department has a new name-Kiswahili and Other African Languages-since 1994, it started as a department of Kiswahili to service the Faculty of Education in 1987. Like the University of Nairobi, the focus is linguistics and literature.

Perhaps the approach taken by the department from the word go, influenced developments in other universities. To begin with all courses, were taught and examined in Kiswahili. Later, when postgraduate MA and D.Phil programmes were introduced, theses had to be and still are written in Kiswahili. Indeed the first Ph.D. candidate in Kiswahili wrote and defended his thesis in Kiswahili in $1996^{3}$. Subsequently, three ${ }^{4}$ more DPhil. theses have been successfully written and defended in Kiswahili while others are in progress. This was probably achieved due to the presence of the first lecturers in the department. Initially, the senior faculty were Tanzanians, e.g. Prof. Said A.M. Khamis (the first chair and presently, a professor at University of Bayreuth), Prof. Mohammed A. Mohammed (now at Sate University of Zanzibar SUZA), Prof. Gibbe (the first D. Phil graduate), Prof. Mbogo, Prof. Nchimbi and the late Mr. Ngozi. While one can safely contend that the tradition of teaching and research in Kiswahili at Moi University trace their origins to Tanzania, it is ironical that to date Ph.D. theses in Kiswahili at the University of Dar es Salaam, Tanzania, are written in English. It is noatable that although the Tanzanians are no longer at Moi University, the tradition that they established of teaching and doing research on Kiswahili in Kiswahili still exists. Further, one needs to appreciate that at Moi University, Kiswahili studies never grew as part of the English or Linguistics department; rather Kiswahili was a distinct department.

In the early 2000s, there was reorganization and merging of departments in Kenyan public universities. The Kiswahili department at Moi University survived the threat of the mergers-thanks to the Mackay Commission that spelt out the significance of Kiswahili at Moi University. The department has instead flexed its muscles. Normally, BA students are admitted into a pool in most public universities in Kenya and subsequently their choose their discipline of specialization from year two. However, at Moi University, there is direct admission through the JAB into the BA Kiswahili degree programme since 2002. The practice is unique to Moi University. The declared capacity in the degree programme is 30 for every academic year. However, between 15 and 20 students stay on in the programme as others opt to change to other degree 
programmes once on campus. So far, the first six candidates have graduated and are largely working with the publishing industry while one is a banker.

\subsection{University of East African Baraton (UEAB)}

This is an SDA-sponsored university that is located about $50 \mathrm{kms}$ from Eldoret town. It was established in 1979 and initially ran degree programmes in Agriculture, Business and Education. From 1992, teaching of Kiswahili was introduced. The first lecturers came from Moi University (including the author of this paper) and largely transferred the focus and tradition of Moi University to UEAB. It is thus possible to talk about a geographical spread of the teaching and research in Kiswahili from Tanzania to Moi University and finally to UEAB.

The student population in UEAB is not just Kenyan; rather international students from both Africa, and overseas largely Philipino and Europeans exist. There is no department of Kiswahili; rather Department of Language and Literature. The Kiswahili programme at UEAB has 3 three courses for beginners, namely, KISW 105; Beginning Kiswahili I, KISW 106 Beginning Kiswahili II and KISW 107 Beginning Kiswahili III. All the courses must be taken in the progressive sequence. They carry zero credits and they are meant for international students who have no background in Kiswahili. The essence is for one to learn to speak, read, write and understand Kiswahili.

The most unique aspect about Kiswahili at UEAB is that all candidates must take a modern language regardless of one's discipline as a prerequisite for graduation. East and Central African students are encouraged to take Kiswahili. There are two courses designed for them, namely, KISW 108 Introduction to Kiswahili Language I and KISW 109 Introduction to Kiswahili Language II. Each course carries three credits. The emphasis in both courses is on fundamentals of grammar with elements of conversation, organs of speech, sound production, comprehension and conversational skills. While the courses enable students to develop their writing skills in composition writing and summary, they also expose them to Kiswahili in various registers.

\subsection{Catholic University of Eastern Africa (CUEA)}

The university is over 20 years old. However, for a long time, the focus of research and teaching was theology. But later other courses including education were introduced. For the last six years, Kiswahili has been taught. Initially, there was no department of Kiswahili. Kiswahili was taught under the department of English. But for the last two years, precisely since the 2006/2007 academic year, a department of Kiswahili was established headed by Kenyans (Mr. Arege and Mr. Kadurenge).

The department teaches Bachelor of Education (BED) students who are being prepared to be high school teachers; and primary and diploma teachers who want to up grade their education to degree level. The total Kiswahili student population is 160 . Interestingly, the department has prepared a BA Kiswahili programme that will be launched in the 2009/2010 academic year. There are also plans to introduce a MA in Kiswahili course soon after. It is not yet clear what the medium of writing thesis will be although there are signs that everything will be done in Kiswahili. 


\section{Summary and Conclusions}

29 This paper sought to discuss research and teaching of Kiswahili in Kenyan universities. It has shown that the history of the research and teaching is closely linked with the history of the state's language policy concerning Kiswahili. For much of the early years of independence, Kiswahili was given lip-service and support as a national language. While the then President was in support of a policy of promoting Kiswahili, the elite in his government who acquired their education and positions of influence through English worked overdrive to frustrate Kiswahili. They wanted to preserve their positions of influence while blocking those who were literate in Kiswahili.

Subsequently, research and teaching of Kiswahili was not stressed not only at the primary and secondary school levels but also at the university level. When the language was introduced at the university, the focus was linguistics and literature and not its grammar. The early lecturers too appear to have been foreign and only taught Kiswahili in the English medium.

31 There was only change of attitude when the Mackay Commission released its report and the government led by President Moi went flat out to emphasize research and teaching of Kiswahili. What is also clear is that research and teaching of Kiswahili since the advent of the second university in 1984, though not consciously, is heavily influenced by the trend established at the second university Moi University. Faced with lack of qualified Kenyans to teach Kiswahili, Moi University relied on Tanzanians who taught all courses in Kiswahili. Teaching also relies heavily on research and publications from Tanzania (Ogechi 2002). Other universities have also slowly adopted this trend. Furthermore, other universities are now writing MA theses in Kiswahili. There are signs that not too long from now the other universities will be writing their doctoral theses in Kiswahili.

The present paper has not overtly addressed geographical aspects of Kiswahili. It needs to be expanded to overtly address the geographical aspects of Kiswahili in Kenya. For instance, while all Kenyan universities have a course on the history and development of Kiswahili, there is need to establish what literature is used as course books. Do all universities address the various theories concerning the origins of Kiswahili? Do they use David Massamba's Historia ya Kiswahili? What is their view about the book? What exactly is the content of the course? At the moment, there appears to have emerged several (especially urban) varieties of Kiswahili including Sheng. What is the position of Kenyan universities concerning the varieties? Given that some creative works now incorporate Sheng, do the scholars address it in their teaching and research? Is any deliberate attempt being made to establish the geographical spread of the variety? Given that Kenyan universities were established up-country and most lecturers are from up-country, to what extent can one talk of Kiswahili teaching and research spreading from the hinterland to the coast? The media, especially the print and electronic media, plays a crucial role in the spread and change of any language. Much of the media in Kenya is owned by up-country people who also employ up-country broadcasters, news anchors and writers. Their Kiswahili is largely influenced by their up-country languages. To what extent is this up- country Kiswahili spreading to the coast? These and more issues need to be addressed in the next phase of research 


\section{BIBLIOGRAPHY}

Amidu, A. A. (1995). Kiswahili, a continental language: How possible is it? (Part 1). Nordic Journal of African Studies 4 (2): 50-72.

Harries, L. (1976). “The nationalization of Swahili in Kenya.” Language in Society 5: 153-64.

King'ei, K. (2002). "The state of research in African Languages: The case of two Kenyan universities." In F.R. Owino (ed.), Speaking African: African Languages for Education and Development. Cape Town: CASAS.

Mazrui, A.A., Mazrui, A. M. (1995). Swahili State and Society: The Political Economy of an African Language. Nairobi: EAEP.

Moi University. (2005). Moi University Strategic Plan 2005-2015. Eldoret: Moi University Press.

Myers-Scotton, C. (1993). Social Motivations for Codeswitching: Evidence from Africa. Oxford: Oxford University Press.

Ogechi, N.O. (2002). “Utegemezi au utegemeano baina ya Kenya na Tanzania katika ukuzaji na uendelezaji wa Kiswahili.” Swahili Forum IX: 155-72.

Ogechi, N.O. (2004). “Athari ya mabadiliko ya mitaala katika uchapishaji kwa Kiswahili nchini Kenya”. Swahili Forum XII: 92-104.

Republic of Kenya (1964). Report of the Kenya Education Commission. Nairobi: English Press Limited. University of Eastern African, Baraton. (1994). University of Eastern African, Baraton, Bulletin 19941996, vol. 6.

University of Nairobi. (1988). University of Nairobi Calendar 1988-1980. Nairobi: UON.

University of Nairobi. (2001). University of Nairobi Calendar 2001-2003. Nairobi: UON.

\section{APPENDIXES}

\section{List of Abbreviations}

\section{BA: Bachelor of Arts}

BED: Bachelor of Education

CPE: Certificate of Primary Education CUEA Catholic University of Eastern Africa KEMU Kenya Methodist University ROK Republic of Kenya

SUZA: State of University of Zanzibar UEAB University of Eastern Africa, Baraton UON University of Nairobi

USIU: United States International University 


\section{NOTES}

1. The period after the abortive coup d'Etat in 1982 saw President Moi employ all means to assert his influence and authority all over Kenya. He went about using influential personalities from different ethnic communities regardless of their educational background. As a result, people illiterate in English but who had influence over their ethnic communities were nominate to parliament. To enable them participate in parliamentary debate, parliament was made officially bilingual in English and Kiswahili.

2. They included the then attorney general, Charles Njonjo, who could not understand how he could introduce legislation in Kiswahili. He said: “... what should I do in drafting legislation?" (Haries 1976: 154)

3. Prof. Abel Gregory Gibbe wrote his PhD on Kiswahili poetry in Kiswahili and graduated in 1996.

4. Prof. Naomi L. Shitemi (1997), Dr. Hannington Oriedo (2002) and Dr. Miriam Bageni Mwita-Ssemanda (2005).

\section{INDEX}

Geographical index: Kenya

\section{AUTHOR \\ NATHAN OYORI OGECHI}

Moi University, Kenya. 